\title{
Characterization and activity of entomopathogenic fungi isolates against "Paraguay tea ampul" (Gyropsylla spegazziniana) (Lizer \& Trelles) (Hemiptera: Psyllidae)
}

\section{Caracterização e atividade de isolados de fungos entomopatogênicos sobre a "ampola da erva-mate" Gyropsylla spegazziniana (Lizer \& Trelles) (Hemiptera: Psyllidae)}

\author{
Marina Andressa Formentini1; Luis Francisco Angeli Alves ${ }^{2 *}$; \\ Maria Elena Schapovaloff'; Ana Paula Mamprim²; \\ Andrea Kusumota Bonini²; Fabiana Gisele da Silva Pinto ${ }^{2}$
}

\begin{abstract}
Paraguay tea is a native crop of southern Brazil and is also socioeconomically important in Paraguay and Argentina. One of the main pests of this crop is Gyropsylla spegazziniana (Hemiptera: Psyllidae). As there are no registered insecticides for this pest in Brazil, the use of entomopathogenic fungi is an alternative method for its control. This study aimed to evaluate and characterize isolates of the entomopathogenic fungi Beauveria spp., Metarhizium anisopliae, Isaria spp. and Lecanicillium spp. on G. spegazziniana. For this purpose, $5^{\text {th }}$ instar nymphs were transferred to Paraguay tea seedlings, followed by spraying of conidial suspensions $\left(1 \times 10^{9}\right.$ conidia $\left.\mathrm{mL}^{-1}\right)$ and then placing the seedlings in polyvinyl chloride (PVC) cages and maintaining them in a temperature-controlled room $\left(26 \pm 1{ }^{\circ} \mathrm{C}\right.$, $12 \mathrm{~h} 00$ photophase, $60 \pm 10 \%$ R.H.). Insect mortality was evaluated daily for 10 days, and the selected isolates were characterized according to their vegetative growth, conidial production in synthetic culture medium and rice and insecticidal activity as well as through molecular analyses, including sequencing the rDNA-ITS region and RAPD analysis. The genus Beauveria spp. was the most efficient, particularly the Unioeste 44 isolate, which caused the greatest total mortality of $G$. spegazziniana $(81.7 \%)$ and showed among the highest conidial production levels on rice, indicating a significant potential to be used in an integrated management program for this pest. Molecular analysis of the rDNA-ITS region allowed the isolates to be identified as B. bassiana and B. brongniartii, and RAPD markers were found to be associated with virulence.
\end{abstract}

Key words: Biological control, Ilex paraguariensis, rDNA-ITS

\section{Resumo}

A erva-mate (Ilex paraguariensis St. Hil.) é uma cultura nativa do Sul do Brasil, tendo grande importância socioeconômica também para o Paraguai e Argentina. Uma das principais pragas da cultura é a Gyropsylla spegazziniana (Hemiptera: Psyllidae), e pelo fato de não existirem inseticidas registrados para essa praga no Brasil, o uso de fungos entomopatogênicos pode ser uma alternativa para o seu controle. O objetivo desse trabalho foi caracterizar isolados dos fungos entomopatogênicos Beauveria

1 Bióloga, Koppert Biological Systems, Piracicaba, SP, Brasil. E-mail: mformentini@koppert.com.br

2 Laboratório de Biotecnologia Agrícola, Universidade Estadual do Oeste do Paraná, UNIOESTE, Cascavel, PR, Brasil. E-mail: luis.alves@unioeste.br; anamamprim@hotmail.com; akbonini@yahoo.com.br; fabiana.pinto@unioeste.br

3 Pesquisadora, Instituto Nacional de Tecnología Agropecuaria, Monte Carlo, Misiones, Argentina. E-mail: eleschapovaloff@ yahoo.com.ar

Author for correspondence 
spp., Metarhizium anisopliae, Isaria spp. e Lecanicillium spp. sobre G. spegazziniana. Para tal, ninfas de $5^{\circ}$ ínstar foram transferidas para mudas de erva-mate, seguido da pulverização das suspensões de conídios $\left(1 \times 10^{9}\right.$ conídios $\left.\mathrm{mL}^{-1}\right)$, e então as mudas foram acondicionadas em gaiolas de PVC (cloreto de polivinila), e mantidas em sala climatizada $\left(26 \pm 1{ }^{\circ} \mathrm{C} ; 12 \mathrm{~h} 00\right.$ de fotofase e U.R. $\left.60 \pm 10 \%\right)$. A mortalidade dos insetos foi avaliada diariamente, por 10 dias, e os isolados selecionados foram comparados entre si por meio do crescimento vegetativo, produção de conídios em meio sintético e em arroz, atividade inseticida e análises moleculares, utilizando-se o sequenciamento da região rDNA-ITS e marcadores RAPD. O gênero Beauveria spp. foi o mais eficiente, em especial o isolado Unioeste 44 que apresentou a maior mortalidade total sobre G. spegazziniana (81.7\%) e uma das maiores produções de conídios em arroz, mostrando potencial significativo para ser usado em programas de manejo integrado da praga. As análises moleculares da região rDNA-ITS possibilitaram a identificação dos isolados como $B$. bassiana e $B$. brongniartii e os marcadores RAPD foram associados à virulência.

Palavras-chave: Controle biológico, Beauveria, Ilex paraguariensis, rDNA-ITS

\section{Introduction}

Paraguay tea (Ilex paraguariensis St. Hil.) has great socioeconomic importance in Argentina, Paraguay and Brazil (southern region). Brazil produced almost 500,000 tons of this product in 2012 (IBGE 2014). Paraguay tea leaves and twigs are used to prepare tea and soluble powder (an instant tea powder) and as a raw material for medicines and cosmetics (ANUÁRIO BRASILEIRO DA ERVAMATE, 2000; IBGE, 2014).

Intensive extractivism of native Paraguay tea and the expansion of agricultural frontiers led to scarcity of this plant, and in the 1970s, Paraguay tea began to be grown in extensive monoculture systems. In parallel, the use of pesticides that are not registered and/or recommended for crops contributes to the formation of an ecologically unbalanced environment, favoring the emergence of pests, including the borer Hedypathes betulinus, the Paraguay tea psyllid, Gyropsylla spegazziniana, the red mite Oligonychus yorthesi (Acari: Tetranychidae), and the caterpillars Thelosia camina (Lepidoptera: Eupterotidae) and Hylesia sp. (Lepidoptera: Hemileucidae) (IEDE; MACHADO, 1989; SAINI; DE COLL, 1993; DIAZ, 1997; BORGES et al., 2003).

G. spegazziniana (Psyllidae), or the "Paraguay tea ampul", is an important pest of this crop because it causes deformation of the young leaves where nymph develops, with the leaves falling off after several weeks. There are few studies on the damage caused by this insect to the crop. In Brazil, the losses from this pest can be nearly $54 \%$, whereas they are up to $35 \%$ in Argentina (RIVERA FLORES, 1983; CHIARADIA et al., 2000). However, despite the importance of this pest, there are few available studies on $G$. spegazziniana, which have been focused on only determining its population dynamics (BORGES et al., 2003; LEITE; ZANOL, 2001; LEITE et al., 2007).

There are no products registered for the control of G. spegazziniana in Brazil (AGROFIT, 2014), indicating the need to search for new control strategies. In this context, studies conducted in Brazil have shown the potential of vegetal extracts (BARZOTTO, 2010; HAAS et al., 2010), and the entomopathogenic fungus Zoophthora radicans (Brefeld) has been observed on 90\% of G. spegazziniana cadavers in Paraguay tea plantations in Brazil and Argentina (ALVES et al., 2009; SOSA-GÓMEZ et al., 1994). Additionally, the susceptibility of $G$. spegazziniana to Beauveria bassiana isolates was recently demonstrated for the first time, revealing encouraging results (ALVES et al., 2013).

So, as done by Ugine et al. (2013), this new interaction must be investigated not only for testing the virulence of the different isolates, but also for the biological characterization, assessing their microbial biocontrol potential. 
Thus, entomopathogenic fungi, particularly B. bassiana, might represent an economical and environmentally suitable option for pest control in Paraguay tea, as has been shown for the borer $H$. betulinus and the red mite $O$. yothersi (OLIVEIRA et al., 2002; BORGES et al., 2011; AGROFIT, 2014). Hence, in the present study, we conducted analyses to select and characterize isolates of entomopathogenic fungi to control the Paraguay tea ampul.

\section{Materials and Methods}

\section{Fungal isolates}

Isolates of the entomopathogenic fungi Beauveria spp., Metarhizium anisopliae, Isaria spp. and Lecanicillium spp. (Table 1) were evaluated against $G$. spegazziniana, and the most effective isolates (causing mortality above 50\%) were compared based on a number of biological parameters (vegetative growth, conidial production in culture media and on rice, and insecticidal activity). Molecular characterization was performed with the aim of comparing the best isolates (highvirulence) with some low-virulence isolates.

\section{Insects}

Paraguay tea branches with closed galls were collected from a crop in Cascavel, PR (24 57' $21^{\prime}$ ”; $53^{\circ} 27^{\prime} 19^{\prime \prime} \mathrm{W}$ ), and $5^{\text {th }}$-instar nymphs (the last instar) were transferred to Paraguay tea plants with a height of approximately $15 \mathrm{~cm}$ at a density of 20 nymphs per seedling, with the aid of a moistened brush. The choice of last-instar nymphs was because when they leave galls (LEITE; ZANOL, 2001) would come into contact with the fungus applied in the field, in addition to being more resistant to manipulation.

\section{Insect assays}

\section{Pre-selection}

Pathogenic isolates were selected based on bioassays carried out in the laboratory. All isolates were grown in sporulation medium (SM; consisting of $0.36 \mathrm{~g} \mathrm{KH}_{2} \mathrm{PO}_{4}, 1.05 \mathrm{~g} \mathrm{Na}_{2} \mathrm{HPO}_{4} \cdot 7 \mathrm{H}_{2} \mathrm{O}, 0.6$ g $\mathrm{MgSO}_{4} \cdot 7 \mathrm{H}_{2} \mathrm{O}, 1 \mathrm{~g} \mathrm{KCl}, 10 \mathrm{~g}$ glucose, $1.58 \mathrm{~g}$ $\mathrm{NaNO}_{3}, 5 \mathrm{~g}$ yeast extract, and $20 \mathrm{~g}$ agar in $1000 \mathrm{~mL}$ of water) for conidial production. After incubation for 10 days $\left(26 \pm 1^{\circ} \mathrm{C}, 12 \mathrm{~h}\right.$ photoperiod), conidia were scraped off the surface of the culture medium and transferred to flat-bottom vials. The conidial concentration was estimated by counting in Neubauer chamber. A conidial suspension with $1 \times$ $10^{9}$ conidia $\mathrm{mL}^{-1}$ was achieved by adding distilled water $+0.01 \%$ Tween 80 (ALVES et al., 1998). Conidial viability was evaluated, and values higher than $90 \%$ were observed.

Samples containing $2 \mathrm{~mL}$ of each isolate suspension with $1 \times 10^{9}$ viable conidia $\mathrm{mL}^{-1}$ were sprayed onto seedlings harboring twenty insects, using an airbrush coupled to an air compressor (0.7 $\mathrm{kgf} \mathrm{cm}^{-2}$ ) at a distance of $10 \mathrm{~cm}$ from the seedlings. As a control, the seedlings were sprayed with distilled water $+0.01 \%$ Tween 80 .

Individual Paraguay tea seedlings were placed in colorless polyvinyl chloride (PVC) cages (13 $\mathrm{cm}$ diameter $\times 40 \mathrm{~cm}$ height) and maintained in an acclimatized room at $26 \pm 1{ }^{\circ} \mathrm{C}$ under a $12 \mathrm{~h}$ photoperiod and $60 \pm 10 \% \mathrm{RH}$. For each isolate, four seedlings were prepared, and each was considered a replicate. All experiments were performed in quadruplicate and were repeated twice. The cages were analyzed daily for a period of 10 days. Dead insects were removed, immersed in a 70\% alcohol solution, for 10 seconds, and placed in a humid chamber, under the same conditions describe above, to allow sporulation and confirm mortality caused by the fungus. Insects that showed no signs of fungal were transferred to oatmeal-dodine medium, as described by Alves et al. (1998), and incubated under the same conditions to isolate the fungus from 
cadavers. In this first phase of the study, only isolates that achieved $50 \%$ total mortality were selected for the biological characterization bioassays.

\section{Biological characterization}

The pre-selected isolates were characterized according to their growth and sporulation in culture media (SM and cooked rice) and their insecticidal activity.

On the media, the isolates were inoculated at three equidistant points on the surface of SM, with 5 replicates (plates) being performed per treatment, and after 7 days of incubation $\left(26 \pm 1{ }^{\circ} \mathrm{C}\right.$, $12 \mathrm{~h}$ photoperiod), the mean diameter $(\mathrm{cm})$ of two randomly selected colonies per plate was measured. For conidial production, these colonies were cut out from the culture media and placed in a test tube containing $10 \mathrm{~mL}$ of sterile distilled water $+0.01 \%$ Tween 80 . The tubes were stirred for one minute in a vortex mixer to extract the conidia from medium surface and quantified in a Neubauer chamber under $400 \times$ magnification.

Cooked rice was prepared in polypropylene plastic bags $(22 \mathrm{~cm}$ wide $\times 35 \mathrm{~cm}$ height $)$ containing $100 \mathrm{~g}$ of parboiled rice $+20 \mathrm{~mL}$ of distilled water. The bags were sealed and autoclaved (30 minutes at $120^{\circ} \mathrm{C}$ ), and after cooling, each bag received 10 $\mathrm{mL}$ of a conidial suspension $\left(1 \times 10^{8}\right.$ conidia $\mathrm{mL}^{-}$ $\left.{ }^{1}\right)$. After shacked, the bags were incubated at $26 \pm$ $1^{\circ} \mathrm{C}$ under a $12 \mathrm{~h}$ photoperiod for 7 days. For each isolate, five bags (replicates) were prepared. Three 1 g samples were collected from each isolate on rice. These samples were transferred to glass tubes with $10 \mathrm{~mL}$ of sterile distilled water $+0.01 \%$ Tween 80 . After vortexing for 1 minute, quantification was carried out in a Neubauer chamber.

The insecticidal activity of the isolates was compared using an experimental methodology similar to that described in the pre-selection experiments, except that the twenty $5^{\text {th }}$-instar nymphs were placed in plastic Petri dishes, and 1
$\mathrm{mL}$ of a suspension of $1 \times 10^{9}$ viable conidia $\mathrm{mL}^{-1}$ was sprayed directly on them using a Potter Tower $\left(0.7 \mathrm{kgf} \mathrm{cm}^{-2}\right)$, which was a sufficient quantity to cover all of the nymphs on plate. The goal of this experiment was fully expose the insects to the entomopathogenic fungus. Then, the insects were transferred to Paraguay tea seedlings. As a control, spraying was performed using only distilled water $+0.01 \%$ Tween 80 . The treatments were prepared with 4 replicates and were evaluated daily for 10 days, considering the cumulative total mortality on the $3^{\text {rd }}, 6^{\text {th }}$ and $10^{\text {th }}$ days. The experiments were repeated twice.

\section{Statistical analysis}

The data were subjected to a test of normality using the Shapiro-Wilk test and analyzed via oneway ANOVA, and means were compared with the Tukey test $(\mathrm{P}<0.05)$, using the statistical program Sisvar (FERREIRA, 2011). The insecticidal activity data were analyzed under factorial design consisting of five treatments and three different evaluation times. The data were previously $\arcsin (\sqrt{ } \mathrm{x} / 100)$ transformed.

\section{Molecular characterization}

Only Beauveria spp. isolates caused mortality of G. spegazziniana, and 9 of them were subjected to molecular characterization. These isolates were the 4 best pre-selected isolates (high-virulence) and the 5 lowest virulence isolates, which were chosen because they were collected from different locations and because were found naturally parasitize different insect species in the field (Table 1). There are many studies evaluating entomopathogenic fungi on the insect pests of various crops. However, in Brazil, the genetic variability of these fungi is poorly known. Thus, in the present study, the molecular characterization of the Beauveria spp. isolates was aimed to determining whether there is a relationship between the initial host, virulence and geographical 
origin. The isolates were selected by sequencing the rDNA-ITS region and RAPD markers to verify the relationship between the molecular profile of the isolates and their geographical origins, initial hosts and virulence in Paraguay tea ampul. For DNA extraction, suspensions of $1 \times 10^{8}$ conidia $\mathrm{mL}^{-1}$ from the selected isolates were inoculated into Erlenmeyer flasks containing $150 \mathrm{~mL}$ of liquid $\mathrm{SM}$, followed by incubation for $72 \mathrm{~h}$ at $120 \mathrm{rpm}$ and $26 \pm 1^{\circ} \mathrm{C}$. Subsequently, the mycelium was collected on a Buchner filter, then washed with sterile distilled water and stored at $-20^{\circ} \mathrm{C}$ until extraction. The genomic DNA of the isolates was extracted according to the methodology described by Azevedo et al. (2000), with some modifications.

For the amplification and sequencing of the rDNA-ITS region, the primers ITS 1 (TCC GTA GGT GAA CCT GCG G) and ITS 4 (TCC TCC GCT TAT TGA TAT GC) were used as forward and reverse primers, respectively (WHITE et al., 1990). Amplification reactions were performed in a $25 \mu \mathrm{l}$ volume, containing $2.5 \mu \mathrm{l} \mathrm{PCR}$ buffer $(200 \mathrm{mM}$ Tris-HCl, $\mathrm{pH} 8.4,500 \mathrm{mM} \mathrm{KCl}, 10 \times$ concentrate), $1.2 \mu \mathrm{MgCl}_{2}(50 \mathrm{mM}), 5.0 \mu \mathrm{dNTPs}(1.5 \mathrm{mM})$, $1 \mu \mathrm{l}$ of each primer $(50 \mathrm{mM}), 0.2 \mu \mathrm{l}$ Taq DNA

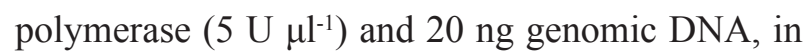
a thermocycler (PTC-MG 200). The amplification program consisted of an initial temperature of $95^{\circ} \mathrm{C}$ $3 \mathrm{~min}^{-1}$, followed by 35 cycles at $94^{\circ} \mathrm{C} 1 \mathrm{~min}^{-1}, 57^{\circ} \mathrm{C}$ $1 \mathrm{~min}^{-1}$, and $72^{\circ} \mathrm{C} \min ^{-1}$, with a final step at $72^{\circ} \mathrm{C}$ $3 \mathrm{~min}^{-1}$. The PCR products were purified with the Wizard $^{\circledR}$ SV Gel and PCR Clean-Up System Kit (Promega), and sequencing was performed with the BigDye ${ }^{\circledR}$ Terminator v3.1 Cycle Sequencing Kit using an ABI 3730 DNA Analyzer. Nucleotide sequences were deposited in GenBank (accession numbers: KC004059 - KC004067) and organized into contigs using Phred (EWING et al., 1998), Phrap (www.phrap.org) and Consed (GORDON et al., 1998) software and compared with the GenBank database. Sequence alignments were analyzed with the software Clustal X-1.83 (THOMPSON et al., 1997). A phylogenetic tree was constructed using the Mega 4.0 program (KUMAR et al., 2004) with the neighbor-joining algorithm (SAITOU; NEI, 1987), through the analysis of 1,000 bootstraps.

For the analysis of RAPD profiles, 13 primers (Operon Technologies ${ }^{\circledR}$ ) that showed consistent banding patterns were selected: OPA 13, OPB 1, OPB 8, OPD 2, OPD 3, OPE 1, OPE 7, OPE 16, OPQ 2, OPQ3, OPZ 19, OPAC 3 and OPAC 9. The reaction mixture was prepared in a $25 \mu \mathrm{l}$ volume [2,5 $\mu$ l PCR buffer (200 mM Tris- HCl, pH 8.8, $500 \mathrm{mM} \mathrm{KCl}$, concentrated $10 \times), 1.5 \mu \mathrm{MgCl}_{2}(50$ $\mathrm{mM}), 2.5 \mu \mathrm{dNTP}(2.5 \mathrm{mM}), 1 \mu \mathrm{l}$ of each primer $(100 \mu \mathrm{M}), 0.2 \mu \mathrm{l}$ Taq DNA polymerase $(5 \mathrm{U} / \mu \mathrm{l})$ and $1 \mu \mathrm{DNA}(20 \mathrm{ng})]$. The amplification reactions (PTC-200 MG) were performed in a thermal cycler programmed for initial denaturation at $94^{\circ} \mathrm{C} 5 \mathrm{~min}^{-1}$, followed by 39 cycles at $92^{\circ} \mathrm{C} 1 \mathrm{~min}^{-1}, 35^{\circ} \mathrm{C} 1 \mathrm{~min}^{-}$ ${ }^{1}$ and $30 \mathrm{sec}$, and $72^{\circ} \mathrm{C} 2 \mathrm{~min}^{-1}$, with a final step at $72^{\circ} \mathrm{C} 5 \mathrm{~min}^{-1}$. Then, the samples were analyzed in $1.4 \%$ agarose gels $(100 \mathrm{~V})$ using a $1 \mathrm{~Kb}$ Plus DNA Ladder (Life Technologies ${ }^{\circledR}$ ) as a molecular weight marker; these gels were stained with $10 \mathrm{mg} \mathrm{mL}^{-1}$ of ethidium bromide and photographed using a UV light source (L Pix Loccus Biotechnology).

The data were analyzed using Bionumerics software (Applied Mathematics, Kortrijk, Belgium, version 2.0). Cluster analyses among the isolates were carried out using the UPGMA method (unweighted pair group method algorithm) and the Jaccard coefficient, at a tolerance level of $3 \%$. 
Table 1. Isolates of entomopathogenic fungi, their origin, and total and confirmed mortality ( \pm SEM) of Gyropsylla spegazziniana after 10 days $\left(1 \times 10^{9}\right.$ conidia $\mathrm{mL}^{-1}, 26 \pm 1^{\circ} \mathrm{C}, 12 \mathrm{~h}$ photoperiod, $\left.60 \pm 10 \% \mathrm{RH}\right)$.

\begin{tabular}{|c|c|c|c|c|}
\hline \multirow{2}{*}{ Isolate } & \multirow{2}{*}{ Host } & \multirow{2}{*}{ Locality } & \multicolumn{2}{|c|}{ Mortality (\%) } \\
\hline & & & Total & Confirmed \\
\hline \multicolumn{5}{|c|}{ Beauveria spp. } \\
\hline Unioeste 44 & Adult of Hemiptera, Pentatomidae & Fazenda Timburi, Toledo, PR & $81.7 \pm 10.38$ & $12.0 \pm 43.1$ \\
\hline Unioeste 38 & Caterpillar of Bombyx mori & Ibaiti, PR & $67.3 \pm 9.19$ & $5.0 \pm 10.6$ \\
\hline CG 716 & Adult of Hedypathes betulinus & Ivaí, PR & $60.1 \pm 11.38$ & $15.1 \pm 11.8$ \\
\hline CNPSo Bb 134 & Piezodorus guildinii & Warta - Londrina, PR & $51.7 \pm 4.85$ & $30.8 \pm 5.9$ \\
\hline Unioeste 52 & Adult of Alphitobius diaperinus & Boa Vista da Aparecida, PR & $48.7 \pm 12.50$ & $23.9 \pm 9.1$ \\
\hline Unioeste 65 & Adult of Anthonomus grandis & Cascavel, PR & $48.4 \pm 5.08$ & $21.1 \pm 15.3$ \\
\hline Unioeste 46 & Adult of Euschithus heros & Cascavel, PR & $41.8 \pm 3.23$ & $37.0 \pm 3.5$ \\
\hline Unioeste 60 & Adult of Chrysomelidae, Coleoptera & Catanduvas, PR & $40.5 \pm 8.45$ & $7.4 \pm 13.1$ \\
\hline Unioeste 64 & Adult of Hedypathes betulinus & Cascavel, PR & $40.4 \pm 2.20$ & $18.2 \pm 3.3$ \\
\hline Unioeste 4 & Larva of Alphitobius diaperinus & Cascavel, PR & $40.2 \pm 8.19$ & $13.9 \pm 14.1$ \\
\hline Unioeste 57 & Hemiptera, Pentatomidae & Cascavel, PR & $36.3 \pm 8.02$ & $12.0 \pm 15.2$ \\
\hline IBCB 21 & Soil & Cascavel, PR & $35.3 \pm 11.82$ & $7.3 \pm 13.4$ \\
\hline Unioeste 70 & Adult of Vatiga manihotae & Marechal C. Rondon, PR & $33.7 \pm 6.92$ & $16.5 \pm 8.2$ \\
\hline Unioeste 59 & Adult of Alphitobius diaperinus & Cascavel, PR & $31.3 \pm 3.29$ & $6.7 \pm 3.2$ \\
\hline CNPSo Bb 159 & Nezara viridula & Warta - Londrina, PR & $26.0 \pm 7.73$ & $10.0 \pm 10.8$ \\
\hline IBCB 34 & Soil & Cascavel, PR & $19.3 \pm 5.15$ & $10.3 \pm 4.9$ \\
\hline IBCB 31 & Nezara viridula & Piracicaba, SP & $19.0 \pm 1.60$ & $3.4 \pm 2.1$ \\
\hline Unioeste 25 & Soil, Paraguay tea crop & Cascavel, PR & $17.5 \pm 1.27$ & $1.3 \pm 1.0$ \\
\hline Unioeste 47 & Adult of Hemiptera, Pentatomidae & Primavera do Leste, MT & $16.8 \pm 4.38$ & $7.0 \pm 15.6$ \\
\hline Unioeste 69 & Adult of Hedypathes betulinus & Ivaí, PR & $15.8 \pm 5.25$ & $6.7 \pm 9.4$ \\
\hline Unioeste 26 & Soil, Paraguay tea crop & Cascavel, PR & $14.4 \pm 3.33$ & $4.0 \pm 2.2$ \\
\hline Unioeste 71 & whitefly nymph (Bemisia tabaci) & Marechal C. Rondon, PR & $13.9 \pm 3.61$ & $6.5 \pm 4.5$ \\
\hline IBCB 486 & Soil - cana & Espírito Santo do Pinhal, SP & $13.0 \pm 3.49$ & $2.5 \pm 4.6$ \\
\hline CNPSo Bb 161 & Anticarsia gemmatalis & Warta - Londrina, PR & $11.8 \pm 2.62$ & $0.0 \pm 0.0$ \\
\hline IBCB 66 & Hypothenemus hampei & São José do Rio Pardo, SP & $10.4 \pm 5.78$ & $2.4 \pm 4.0$ \\
\hline CNPSo Bb 282 & Bee Europa & Warta - Londrina, PR & $9.0 \pm 4.68$ & $1.5 \pm 1.4$ \\
\hline IBCB 548 & Soil- coffee & Matão, SP & $6.1 \pm 3.98$ & $2.3 \pm 2.9$ \\
\hline \multicolumn{5}{|c|}{ Metarhizium anisopliae } \\
\hline CNPSo Ma 548 & Solenopsis sp. & Porto Alegre, RS & $28.7 \pm 6.45$ & $5.3 \pm 7.6$ \\
\hline IBCB 353 & Mahanarva fimbriolata & Valparaíso, SP & $25.0 \pm 3.29$ & $1.3 \pm 7.4$ \\
\hline CNPSo Ma 554 & Mahanarva fimbriolata & São José do Rio Claro, MT & $16.4 \pm 0.60$ & $9.9 \pm 2.7$ \\
\hline IBCB 352 & Soil & Valparaíso, SP & $15.9 \pm 3.78$ & $2.9 \pm 8.1$ \\
\hline IBCB 418 & Caterpillar & Iporanga, SP & $14.4 \pm 5.30$ & $8.1 \pm 6.8$ \\
\hline IBCB 364 & Bicudo & Araras, SP & $11.7 \pm 1.69$ & $4.7 \pm 2.6$ \\
\hline CNPSo Ma 550 & Mahanarva posticata & Alagoas & $10.2 \pm 0.16$ & $3.8 \pm 1.8$ \\
\hline Unioeste 22 & Soil, Paraguay tea crop & Cascavel, PR & $9.1 \pm 0.43$ & $2.7 \pm 5.5$ \\
\hline CNPSo Ma 549 & Mahanarva posticata & Pernambuco & $8.6 \pm 4.61$ & $0.0 \pm 0.0$ \\
\hline \multicolumn{5}{|c|}{$\begin{array}{l}\text { Isaria spp. } \\
\text { Ins. }\end{array}$} \\
\hline Turfal 01 & Unknown & Unknown & $27.1 \pm 5.08$ & $8.5 \pm 5.9$ \\
\hline CNPSo Pae 355 & Unknown & Unknown & $16.3 \pm 5.50$ & $6.3 \pm 1.0$ \\
\hline CNPSo Pae 217 & Anticarsia gemmatalis & Warta - Londrina, PR & $14.0 \pm 4.73$ & $0.0 \pm 0.0$ \\
\hline CNPSo Pae 219 & Anticarsia gemmatalis & Warta - Londrina, PR & $11.4 \pm 1.83$ & $1.3 \pm 2.9$ \\
\hline CNPSo Pae 218 & Anticarsia gemmatalis & Warta - Londrina, PR & $9.5 \pm 3.60$ & $0.0 \pm 3.9$ \\
\hline
\end{tabular}

continued 
continuation

\begin{tabular}{lccrr} 
IBCB 201 & Soil & Cascavel, PR & $7.4 \pm 1.47$ & $1.6 \pm 1.3$ \\
IBCB 500 & Soil & Monte Alegre, SP & $7.4 \pm 1.53$ & $5.8 \pm 2.4$ \\
IBCB 236 & Coffee & Poloni, SP & $6.1 \pm 3.03$ & $4.9 \pm 3.9$ \\
IBCB 638 & Bemisia tabaci & Unknown & $5.8 \pm 1.46$ & $4.2 \pm 2.7$ \\
& & Lecanicillium spp. & \\
\hdashline Turfal 01 & Unknown & Unknown & $30.4 \pm 4.82$ & $22.1 \pm 6.2$ \\
Turfal 02 & Unknown & Unknown & $28.4 \pm 6.26$ & $15.6 \pm 12.9$ \\
IBCB 616 & Myzus persilae & Campinas, SP & $18.1 \pm 3.13$ & $13.3 \pm 4.2$ \\
IBCB 618 & Myzus persilae & Campinas, SP & $17.0 \pm 4.70$ & $10.6 \pm 7.8$ \\
\hline
\end{tabular}

\section{Results and Discussion}

Pre-selection

All of the isolates were pathogenic with wide variation among their activities (total mortality ranged from 5.8 to $81.7 \%$ and confirmed mortality between 0 and $37.0 \%$ ). Only four isolates showed total mortality values above $50 \%$ and higher values of confirmed mortality, which were selected for the second phase of the study (Unioeste 44, Unioeste 38, CG 716 and CNPSo 134). No mortality was observed in the control. The other fungal species evaluated did not reach $30 \%$ total mortality (Table 1 ).

The ability of the fungi to develop the complete cycle is different for each insect, and low percentages of confirmed mortality have frequently been observed, as in studies evaluating the activity of different entomopathogenic fungi against Mahanarva fimbriolata (Stål) (Hemiptera: Cercopidae) and Collaria scenica (Hemiptera: Miridae) (LOUREIRO et al., 2005; BARBOZA et al., 2011), whereas in a study with Tetraleurodes acaciae (Quaintance) (Insecta, Hemiptera: Aleyrodidae) have found no signs of death caused by fungi in the targeted insects (VILLACARLOS et al., 2003).

In addition, Padulla (2007) studied B. bassiana infections of Diaphorina citri (Kuwayama) (Hemiptera: Psyllidae) and as observed here, there were similar symptoms in cadavers, such as a reduced body volume, without any sign of conidiogenesis.
Nevertheless, a high percentage of total mortality implies a reduction of the pest population. However, conidiogenesis in cadavers is an important factor in the conservation of the disease and fungal conservation in the field but is directly linked to environmental conditions as well as the isolate and host size (ALVES, 1998). Furthermore, after fungal penetration through the insect tegument, death can occur indirectly, through mechanical damage, nutrient exhaustion and physiological/biochemical alterations, and/or directly, via intoxication and organ dysfunction (HAJEK; ST. LEGER, 1994; ALVES, 1998). Thus, it is possible that in dead insects without any presence of fungi on their surface, the pathogen was not able to complete its cycle of infection, which according to Shimazu (1994), is a relatively common phenomenon.

The other evaluated fungal species total mortality of the insects did not reach 30\% (Table $1)$. The variation in mortality caused by different species highlights the importance of testing each species to identify appropriate isolates to be used for a particular pest.

The genus Beauveria stood out from the other entomopathogenic fungi, showing the highest percentage of both total and confirmed mortality. The high activity of Beauveria spp. related to microbial control is well known, with several successful examples being reported (ALVES et al., 2010), which can be attributed to the ability of these fungi to produce a variety of secondary metabolites involved in pathogenesis and virulence as well 
as exhibiting more proteins and enzymes related to cellular metabolism. Additionally, these fungi exhibit an increased number of genes that encode toxins similar to those of bacteria compared with other species of entomopathogenic fungi (XIAO et al., 2012).

\section{Biological characterization}

Regarding the vegetative growth, Unioeste 38 showed the greatest mean diameter $(3.2 \mathrm{~cm})$, followed by the isolates CNPSo Bb 134, Unioeste 44 and CG 716, all of which exhibited significant differences from each other. Rohde et al. (2006), Santoro et al. (2008) and Petlamul and Prasertsan (2012) observed significant variations among the analyzed isolates as well.
The isolate Unioeste 38 also produced the greatest number of conidia in artificial medium $(\mathrm{SM})$, at $13.0 \times 10^{7}$ conidia colony $^{-1}$, with a positive correlation between colony size and production. Similar results were observed by Potrich et al. (2006) and Petlamul and Prasertsan (2012). The other isolates showed significant variation, ranging from 0.1 to $4.4 \times 10^{7}$ conidia colony ${ }^{-1}$. Regarding the production of conidia on rice, CNPSo $\mathrm{Bb} 134$ exhibited the highest production $\left(4.7 \times 10^{7}\right.$ conidia $\mathrm{g}^{-1}$ rice), although it was statistically similar to Unioeste 44 , which produced $4.2 \times 10^{7}{\text { conidia } \mathrm{g}^{-1}}^{-1}$ rice (Table 2). The high production of both isolates in rice is a important result because Unioeste 44 caused the greatest percentage of total mortality in Paraguay tea ampul, and CNPSo Bb 134 displayed the best conidiogenesis in cadavers $(30.8 \%$ confirmed mortality), which is of great importance when we take into account the spread of the disease in the field.

Table 2. Colony diameter and conidial production $( \pm$ SEM) of conidia in synthetic culture medium and cooked rice culture medium among four Beauveria bassiana isolates, after 7 days of incubation $\left(26 \pm 1^{\circ} \mathrm{C}, 12 \mathrm{~h}\right.$ photophase).

\begin{tabular}{lccc}
\hline \multicolumn{1}{c}{ Isolates } & $\begin{array}{c}\text { Mean diameter of colonies } \\
(\mathrm{cm})\end{array}$ & $\begin{array}{c}\text { Mean conidial production/ } \\
\text { colonies }{ }^{1}\end{array}$ & $\begin{array}{c}\text { Mean conidial production in } \\
\text { colonies/rice } / \mathrm{g}^{2}\end{array}$ \\
\hline Unioeste 44 & $2.4 \pm 0.03 \mathrm{~d}$ & $0.1 \pm 1.64 \mathrm{c}$ & $4.2 \pm 0.95 \mathrm{ab}$ \\
Unioeste 38 & $3.2 \pm 0.04 \mathrm{a}$ & $13.0 \pm 1.11 \mathrm{a}$ & $2.0 \pm 0.31 \mathrm{c}$ \\
CG 716 & $2.2 \pm 0.06 \mathrm{e}$ & $0.4 \pm 2.51 \mathrm{c}$ & $3.0 \pm 1.54 \mathrm{bc}$ \\
CNPSo Bb 134 & $3.0 \pm 0.02 \mathrm{~b}$ & $4.4 \pm 2.83 \mathrm{~b}$ & $4.7 \pm 4.91 \mathrm{a}$ \\
\hline \multicolumn{1}{c}{ CV (\%) } & 3.53 & 12.3 & 14.6 \\
\hline
\end{tabular}

${ }^{1}$ Average number of conidia per colony $\times 10^{7} ;{ }^{2}$ average number of conidia per gram of rice $\times 10^{7}$

Means $( \pm$ SEM) followed by the same letter in the column do not differ by the Tukey test $(\mathrm{P}<0.05)$.

The values obtained through this type of testing vary greatly among studies. However, it is difficult to compare results because a number of factors, such as incubation conditions, the type and quality of the culture medium and the genetic variability of isolates, can influence such results (POTRICH et al., 2006; ROHDE et al., 2006). The variation in production by the isolates, observed among different culture media, is noteworthy, as observed for Unioeste 44, which showed the lowest conidial production among the isolates in synthetic medium, but the second highest production in rice.

Regarding insecticidal activity, all isolates showed similar results from pre-selection study, even exposing the insects body to higher conidial concentration, mortality range from 61.3 to $82.2 \%$. So no statistical difference between mortality caused by the isolates was observed (Table 3). As observed previously, confirmed mortality was low and rang from 13.8 to $23.8 \%$, with no statistical difference. 
Based on virulence assay, Unioeste 44 isolate has a good potential to cause great impact on insect population.

The use of entomopathogenic fungi for biological control involves high conidia production, obtained through a large-scale process, which must have low cost (e.g., using cooked rice). In addition, high-virulence isolates exhibiting poor development on rice (large scale culture media), as observed for Unioeste 38 in this study, cannot be recommended as biocontrol agents. Thus, we conclude that biological characterization including the parameters evaluated in the present study is necessary to develop a biological control program for a particular pest.

Table 3. Total and confirmed mortality $( \pm \mathrm{SEM})$ of Gyropsylla spegazziniana caused by Beauveria bassiana isolates on the $3^{\text {rd }}, 6^{\text {th }}$ and $10^{\text {th }}$ days after fungus application $\left(1 \times 10^{9}\right.$ conidia $\mathrm{mL}^{-1}, 26 \pm 1{ }^{\circ} \mathrm{C}, 12 \mathrm{~h}$ photoperiod, $\left.60 \pm 10 \%\right)$.

\begin{tabular}{cccccc}
\hline Treatment & 3 days & 6 days & 10 days & $\begin{array}{c}\text { Total mortality } \\
(\%)\end{array}$ & $\begin{array}{c}\text { Confirmed } \\
\text { mortality (\%) }\end{array}$ \\
\hline Control & $0.0 \pm 0.0 \mathrm{Ba}$ & $0.0 \pm 0.0 \mathrm{Ba}$ & $0.0 \pm 0.0 \mathrm{Ba}$ & $0.0 \pm 0.0 \mathrm{~B}$ & $0.0 \pm 0.0$ \\
Unioeste 44 & $11.4 \pm 1.7 \mathrm{ABb}$ & $45.4 \pm 3.4 \mathrm{Aa}$ & $33.2 \pm 6.5 \mathrm{Aa}$ & $82.2 \pm 17.8 \mathrm{~A}$ & $23.8 \pm 0.5$ \\
Unioeste 38 & $17.7 \pm 6.4 \mathrm{Aa}$ & $32.5 \pm 1.9 \mathrm{Aa}$ & $14.4 \pm 7.5 \mathrm{Aba}$ & $64.7 \pm 13.1 \mathrm{~A}$ & $18.8 \pm 0.8$ \\
CG 716 & $11.9 \pm 7.2 \mathrm{Aba}$ & $22.6 \pm 10.0 \mathrm{Aba}$ & $26.5 \pm 9.4 \mathrm{Aa}$ & $61.9 \pm 11.5 \mathrm{~A}$ & $13.8 \pm 0.6$ \\
CNPSo 134 & $18.3 \pm 1.8 \mathrm{Aa}$ & $28.7 \pm 5.1 \mathrm{Aa}$ & $14.4 \pm 1.6 \mathrm{Aba}$ & $61.3 \pm 10.9 \mathrm{~A}$ & $22.4 \pm 0.9$ \\
\hline
\end{tabular}

* Original data are shown; for statistical analyses, the data were $\arcsin (\sqrt{ } \mathrm{x} / 100)$ transformed

Means $( \pm$ SEM) followed by the same capital letters in a column and small letters in a row do not differ significantly by the Tukey test $(\mathrm{P}<0.05)$.

Treatment $\times$ Time $=0.271$; independent factors.

\section{Molecular characterization}

The molecular characterization of the isolates revealed no polymorphism in the length of the rDNA region among the isolates of Beauveria spp. as a fragment of approximately $540 \mathrm{bp}$ was amplified for all isolates. The sequences of fragments were compared with data from GenBank, and the isolates were characterized as B. bassiana or B. brongniartii with a high degree of identity, with only 6 different nucleotides being observed between the two species. The analyzed isolates came from different hosts and geographic locations (Table 1). Nevertheless, in the consensus tree based on ITS sequences, the isolates were distributed into three distinct groups: those identified as $B$. brongniartii were all grouped together (Group A) and were separated from those identified as $B$. bassiana, which were partitioned into groups $\mathrm{B}$ and $\mathrm{C}$, the latter of which included only Unioeste 38 (Figure 1). The potential use of virulent isolates to control the Paraguay tea ampul suggests the need for molecular confirmation of the taxonomic identity of the fungus.

The obtained RAPD patterns revealed 225 loci, most of which $(92.9 \%)$ were polymorphic. The size of the amplified bands ranged from $250 \mathrm{bp}$ to 2500 $\mathrm{bp}$, and the number of bands present was 4 (OPB 1, OPB 8 e OPD2) a 17 (OPAC 3). The isolates were divided into groups $\mathrm{A}$ and $\mathrm{B}$, with a similarity level above $40 \%$ between them. Group A was represented by the isolates of $B$. brongniartii (except Unioeste 38 ), with over $60 \%$ similarity being observed between them, except for the isolate CNPSo 134 , which showed less similarity to the others (41\%). Group B included only B. bassiana species, with 55\% similarity (Figure 2). The proportion of monomorphic loci between the most virulent isolates was low $(16.2 \%)$. 
Figure 1. Dendrogram of the ITS sequences of 9 isolates of Beauveria spp. generated with Mega version 4.0 using the neighbor-joining algorithm, through 1000 bootstrap analysis. The tree was analyzed using $B$. brongniartii, B. bassiana and B. amorpha as outgroups.

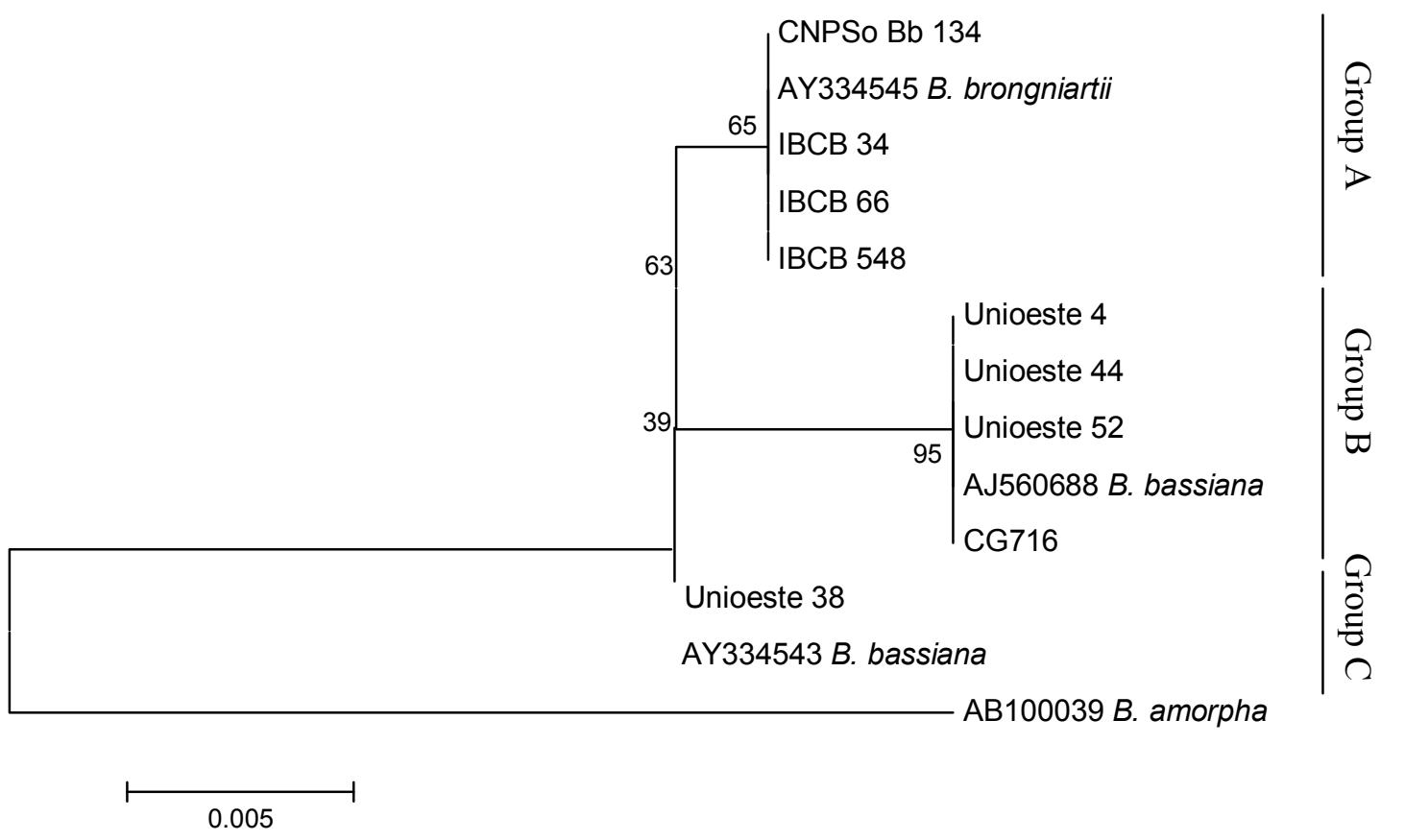

Figure 2. Cluster analysis of 9 isolates of Beauveria spp. using RAPD markers. The dendrogram was generated via UPGMA, with the Jaccard index at 3\% tolerance. The percentages of total mortality of G. spegazziniana and the Beauveria spp. species are indicated in parentheses (ba: B. bassiana; br: B. brongniartii).
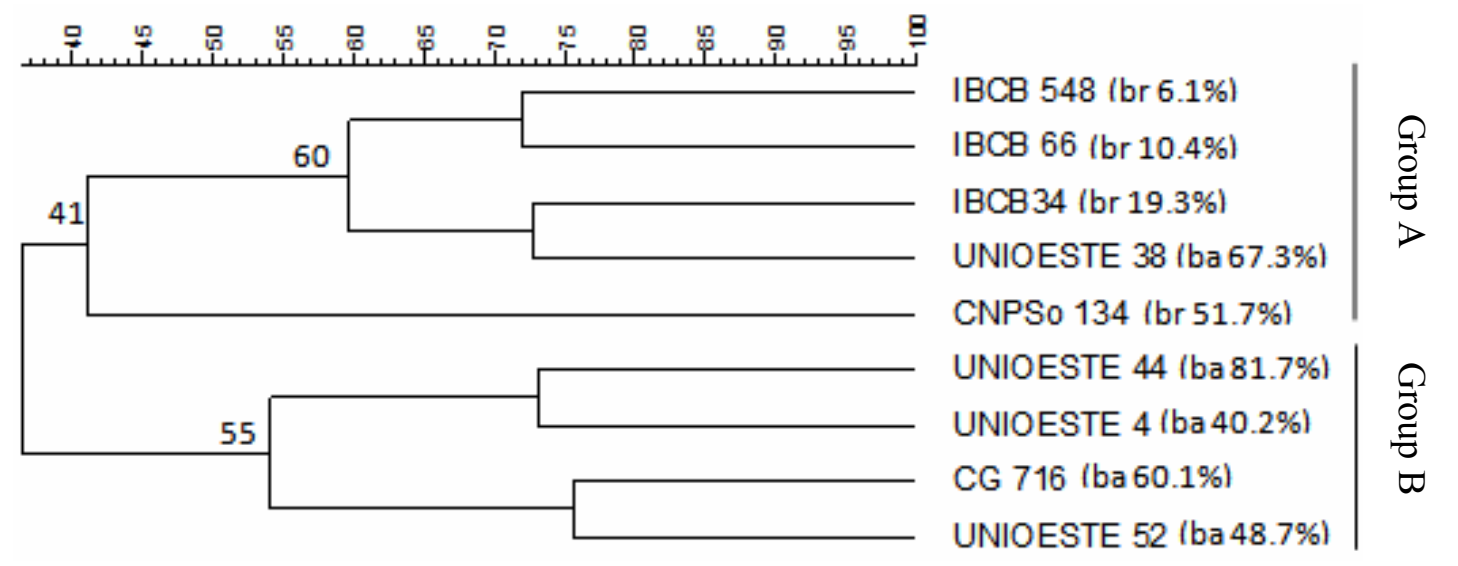

Although some studies have reported a present study, either through analysis of the rDNArelationship between the molecular profile of ITS region or the groups generated via RAPD isolates of entomopathogenic fungi and their initial host (CARNEIRO et al., 2008; OLIVEIRA et al., 2011) or geographical origin (FERNANDES et al., 2009), such a relationship was not found in the analysis, similar to the results of Becerra-Velásquez et al. (2007) and Mendonça et al. (2012).

Regarding RAPD profiles and virulence profiles, Group A consisted of the less virulent isolates, 
except for Unioeste 38 and CNPSo 134, whereas Group B included only more virulent isolates than the other group. The sequencing of the rDNA region showed similar results, except for Unioeste 38, which formed a separate group. This relationship between RAPD profiles and virulence was also observed by Santoro et al. (2008) and Carneiro et al. (2008), who observed clustering of the most virulent isolates, although some isolates of low pathogenicity belonged to the same group.

It was recently suggested that $B$. bassiana is a nonspecialist entomopathogen, with the environment being one of main selective factors in the genotypic evolution of this species (FERRI et al., 2012). In line with this suggestion, high genetic variability has been demonstrated among entomopathogenic fungi, and the level of polymorphism can be highly variable even within the same species (FERNANDES et al., 2006).

Thus, the isolates of genus Beauveria presented higher activity against the ampul, and it can be concluded that the Unioeste 44 isolate show great potential for the control of $G$. spegazziniana. Furthermore, from a practical standpoint, Unioeste 44 and CNPSo 134 isolates good conidial production in rice (large-scale production method) and the last isolate caused the second higher confirmed mortality among the evaluated isolates, demonstrating great potential for use in a future biological control program targeting the Paraguay tea ampul.

Studies performed under field conditions will be necessary to verify the insecticidal activity of these isolates. Additionally, rDNA-ITS and RAPD markers can be employed to identify isolates of Beauveria spp. and are useful for detecting inter and intra-specific variability within this genus. Thus, these markers could be applied in biological pest control programs.

\section{Acknowledgments}

We thank CNPq, CAPES and the Fundação Araucária for financial support of this research.

\section{References}

ALVES, S. B. Fungos entomopatogênicos. In:

(Ed.). Controle microbiano de insetos. 2. ed. Piracicaba: Fealq, 1998. p. 289-381.

ALVES, S. B.; ALMEIDA, J. E. M.; MOINO JUNIOR, A.; ALVES, L. F. A. Técnicas de laboratório. In: ALVES, S. B. (Ed.). Controle microbiano de insetos. 2. ed. Piracicaba: Fealq, 1998. p. 637-711.

ALVES, L. F. A.; LEITE, L. G.; OLIVEIRA, D. G. P. Primeiro registro de Zoophthora radicans (Entomophthorales: Entomophthoraceae) em adultos da ampola-da-erva-mate, Gyropsylla spegazziniana Lizer \& Trelles (Hemiptera: Psyllidae), no Brasil. Neotropical Entomology, Piracicaba, v. 38, n. 5, p. 697-698, 2009.

ALVES, L. F. A.; NEVES, P. M. J. O.; FARIA, M. R. Recomendações para utilização de fungos entomopatogênicos no controle de pragas. Piracicaba: Editora Pedagógica e Universitária Ltda, 2010. 52 p.

ALVES, L. F. A.; FORMENTINI, M. A.; FANTI, A. L. P.; SCHAPOVALOFF, M. E.; BARZOTTO, I. L. M. Susceptibility of Gyropsylla spegazziniana (Lizer \& Trelles) (Hemiptera: Psyllidae) to Beauveria bassiana (Bals.) Vuill. Arquivos do Instituto Biológico, São Paulo, v. 80, n. 3, p. 363-366, 2013.

ANUÁRIO BRASILEIRO DA ERVA-MATE. Gazeta de comunicações. Santa Cruz do Sul: Gazeta de Comunicações, 2000. 80 p.

AZEVEDO, A. C. S.; FURLANETO, M. C.; SOSAGÓMEZ, D. R.; FUNGARO, M. H. P. Molecular characterization of Paecilomyces fumosoroseus (Deuteromycotina: Hyphomycetes) isolates. Scientia Agricola, Piracicaba, v. 57, n. 4, p. 729-732, 2000.

BARBOZA, M. R.; SILVA, D. N.; LUSTOSA, S. B. C.; HIROSE, E. Patogenicidade do fungo entomopatogênico Beauveria bassiana sobre o percevejo Collaria scenica (Hemiptera: Miridae). Ambiência, Guarapuava, v. 7, n. 3, p. 473-480, 2011.

BARZOTTO, I. L. M. Atividade inseticida de extratos vegetais sobre Gyropsylla spegazziniana (Lizer \& Trelles, 1917) (Hemiptera: Psyllidae). 2010. Dissertação (Mestrado em Engenharia Agrícola) - Universidade Estadual do Oeste do Paraná, Cascavel. 
BECERRA-VELÁSQUEZ, V.; CÁRCAMO, M. P.; MERIÑO, C. R.; IGLESIAS, A. F.; DURÁN, J. F. Intraspecific differentiation of Chilean isolates of the entomopathogenic fungi Metarhizium anisopliae var. anisopliae as revelead by RAPD, SSR and ITS markers. Genetics and Molecular Biology, São Paulo, v. 30, n. 1, p. 89-99, 2007.

BORGES, L. R.; LÁZZARI, S. M. N.; LÁZZARI, F. A. Comparação dos sistemas de cultivo nativo e adensado de erva mate, Ilex paraguariensis St. Hil., quanto à ocorrência e flutuação populacional de insetos. Revista Brasileira de Entomologia, São Paulo, v. 47, n. 4, p. 563568, 2003.

BORGES, L. R.; LAZZARI, S. M. N.; BORGESARRIAGADA, L. R.; IEDE, E. T. Eficácia Beauveria bassiana para o controle Hedypathes betulinus em ervamate, Ilex paraguariensis. Floresta, Curitiba, v. 41, n. 2, p. 313-320, 2011.

CARNEIRO, A. A.; GOMES, E. A.; GUIMARÃES, C. T.; FERNANDES, F. T.; CARNEIRO, N. P.; CRUZ, I. Molecular characterization and pathogenicity of isolates of Beauveria spp. to fall armyworm. Pesquisa Agropecuária Brasileira, Brasília, v. 43, n. 4, p. 513-520, 2008.

CHIARADIA, L. A.; MILANEZ, J. M.; SABEDOT, S. M. Caracterização e danos da ampola-da-erva-mate. Pesquisa Agropecuária Catarinense, Florianópolis, v. 13, n. 1, p. 50-53, 2000.

DIAZ, D. Y.F. Perspectivas del manejo integrado de plagas en yerba mate. In: CONGRESSO SUL-AMERICANO DA ERVA-MATE, REUNIÃO TÉCNICA DO CONE SUL SOBRE A CULTURA DA ERVAMATE, 2.; 1., 1997, Curitiba. Anais... Curitiba: Embrapa Florestas, 1997. p. 371-390.

EWING, B.; HILLIER, L.; WENDL, M. C.; GREEN, P. Base-calling of automated sequencer traces using phred. I. Accuracy assessment. Genome Research, Washington, v. 8, n. 3, p. 175-185, 1998.

FERNANDES, E. K. K.; COSTA, G. L.; MORAES, A. M. L.; ZAHNER, V.; BITTENCOURT, V. R. E. P. Study on morphology, pathogenicity, and genetic variability of Beauveria bassiana isolates obtained from Boophilus microplus tick. Parasitology Research, Düsseldorf, v. 98, n. 4, p. 324-332, 2006.

FERNANDES, É. K. K.; MORAES, Á. M. L.; PACHECO, R. S.; RANGEL, D. E. N.; MILLER, M. P.; BITTENCOURT, V. R. E. P.; ROBERTS, D. W. Genetic diversity among Brazilian isolates of Beauveria bassiana: comparisons with non-Brazilian isolates and other
Beauveria species. Journal of Applied Microbiology, Oxford, v. 107, n. 4, p. 760-774, 2009.

FERREIRA, D. F. Sisvar: a computer statistical analysis system. Ciência e Agrotecnologia, Lavras, v. 35, n. 6, p. 1039-1042, 2011.

FERRI, D. V.; MUNHOZ, C. F.; NEVES, P. M. O.; FERRACIN, L. M.; SARTORI, D.; VIEIRA, M. L. C.; FUNGARO, M. H. P. Genetic variability of Beauveria bassiana and a DNA marker for environmental monitoring of a highly virulent isolate against Cosmopolites sordidus. Indian Journal of Microbiology, Delhi, v. 52, n. 4, p. 569574, 2012.

GORDON, D.; ABAJIAN, C.; GREEN, P. Consed: a graphical tool for sequence finishing. Genome Research, Washington, v. 8, n. 4, p. 195-202, 1998.

HAJEK, A. E.; ST. LEGER, R. J. Interactions between fungal pathogens and insect hosts. Annual Review Entomology, Palo Alto, v. 39, n. 1, p. 293-322, 1994.

HAAS, J.; TOMKIEL, M. V.; ALVES, L. F. A.; FANTI, A. L. P. Efeito de óleo de sementes de nim (Azadirachta indica A. Juss.) sobre Gyropsylla spegazziniana (Lizer \& Trelles), na cultura da erva-mate (Ilex paraguariensis St. Hil.). Revista Brasileira de Agroecologia, Porto Alegre, v. 5, n. 2, p. 194-199, 2010.

INSTITUTO BRASILEIRO DE GEOGRAFIA E ESTATÍSTICA - IBGE. Produção Agrícola Municipal - culturas temporárias e permanentes. Rio de Janeiro: IBGE, 2014. Disponível em: <http://www.ibge.gov.br/ home/estatistica/economia/pam/2012/default.shtm>. Acesso em: 31 mar. 2014.

IEDE, E. T.; MACHADO, D. C. Pragas de erva-mate (Ilex paraguariensis St. Hil.) e seu controle. Boletim de Pesquisa Florestal, Colombo, v. 18-19, p. 51-60, 1989.

KUMAR, S.; TAMURA, K.; NEI, M. Mega 3: integrated software for molecular evolutionary genetics analysis and sequence alignment. Briefings in Bioinformatics, Oxford, v. 5, n. 2, p. 150-163, 2004.

LEITE, M. S. P.; ZANOL, K. M. R. Biologia e morfologia de Gyropsylla spegazziniana (Lizer y Trelles) (Hemiptera, Psyllidae). Acta Biologica Paranaense, Curitiba, v. 30, n. 1, p. 19-34, 2001.

LEITE, M. S. P.; ZANOL, K. M.; IEDE, E. T.; PENTEADO, S. R. C. Flutuação populacional de Gyropsylla spegazziniana (Lizer y Trelles) (Hemiptera, Psyllidae) e de seus inimigos naturais em erva-mate no município de São Mateus do Sul, PR, Brasil. Revista Brasileira de Entomologia, Curitiba, v. 51, n. 4, p. 520523, 2007. 
LOUREIRO, E. S.; BATISTA FILHO, A.; ALMEIDA, J. E. M.; PESSOA, L. G. A. Seleção de isolados de Metarhizium anisopliae (Metsch.) Sorok. contra a cigarrinha da raiz da cana-de-açúcar Mahanarva fimbriolata (Stål) (Hemiptera: Cercopidae) em laboratório. Neotropical Entomology, Londrina, v. 34, n.5, p.791-798, 2005.

MENDONÇA, M. C.; SANTOS, M. F.; SILVA-MANN, R.; FERREIRA, J. M. RAPD, Microsatellites markers in the genetic diversity characterization of Beauveria bassiana (Bals.) Vuill. isolates. Tropical and Subtropical Agroecosystems, México, v. 15, n. 1, p. 117-124, 2012.

OliveIRA, R. C.; AlVES, L. F. A.; NEVES, P. M. O. J. Suscetibilidade de Oligonychus yothersi (Acari: Tetranychidae) ao fungo Beauveria bassiana. Scientia Agricola, Piracicaba, v. 59, n.1, p. 187-189, 2002.

OLIVEIRA, D. G. P.; PINTO, F. G. S.; BARCELLOS, F. G.; ALVES, L. F. A.; HUNGRIA, M. Variabilidade genética de isolados de Beauveria spp. e virulência ao cascudinho Alphitobius diaperinus Panzer (Coleoptera: Tenebrionidae). Semina: Ciências Agrárias, Londrina, v. 32, n. 1, p. 147-156, 2011.

PADULLA, L. F. L. Estudo de fungos entomopatogênicos para o controle de ninfas do psilídeo Diaphorina citri Kuwayama (Hemiptera: Psyllidae). 2007. Dissertação (Mestrado em Ciências) - Escola Superior de Agricultura Luiz de Queiroz, Piracicaba.

PETLAMUL, W.; PRASERTSAN, P. Evaluation of strains of Metarhizium anisopliae and Beauveria bassiana against Spodoptera litura on the basis of their virulence, germination rate, conidia production, radial growth and enzyme activity. Mycobiology, Yonsei, v. 40, n. 2, p. 111-116, 2012.

POTRICH, M.; ALVES, L. F. A.; MERTZ, N. R.; SILVA, E. R. L. Avaliação de Beauveria bassiana (Bals.) Vuill. e Metarhizium anisopliae (Metsch.) Sorok. para controle de Sitophilus zeamais (Coleoptera: Curculionidae). BioAssay, Piracicaba, v. 1, n. 12, p. 1-9, 2006.

RIVERA FLORES, S. E. Control del psilido de Ia yerba mate (Gyropsilla spegazziniana Liz.). Cerro Azul: INTA/ Estación Experimental Agropecuária Misiones, 1983. 12 p. (Informe técnico, 39).

ROHDE, C.; ALVES, L. F. A.; NEVES, P. M. O. J.; ALVES, S. B.; SILVA, E. R. L.; ALMEIDA, J. E. M. Seleção de isolados de Beauveria bassiana (Bals.) Vuill. e Metarhizium anisopliae (Metsch.) Sorok. contra o Cascudinho Alphitobius diaperinus (Panzer) (Coleoptera: Tenebrionidae). Neotropical Entomology, Londrina, v. 35, n. 2, p. 231-240, 2006.
SAINI, E. D.; DE COLL, O. R. Enemigos naturales de los insectos y ácaros perjudiciales al cultivo de la yerba mate en la Argentina. Montecarlo: INTA. E. E. A., 1993. $32 \mathrm{p}$.

SAITOU, N.; NEI, M. The neighbor-joining method: a new method for reconstructing phylogenetic trees. Molecular Biology and Evolution, Texas, v. 4, n. 4, p. 406-425, 1987.

SANTORO, P. H.; NEVES, P. M. O. J.; ALEXANDRE, T. M.; SARTORI, D.; ALVES, L. F. A.; FUNGARO, M. E. P. Selection of Beauveria bassiana isolates to control Alphitobius diaperinus. Journal of Invertebrate Pathology, Urbana, v. 97, n. 2, p. 83-90, 2008.

SISTEMAS DE AGROTÓXICOS FITOSSANITÁRIOS - AGROFIT. Ministério da Agricultura, Pecuária e Abastecimento: Coordenação Geral de Agrotóxicos e Afins/DFIA/DAS. Brasília: MAPA, 2014. Disponível em: $\quad<$ http://extranet.agricultura.gov.br/agrofit_cons/ principal_agrofit_cons $>$. Acesso em: 20 mar. 2014.

SOSA-GÓMEZ, D. R.; KITAJIMA, E. W.; ROLON, M. E. First records of entomopathogenic diseases in the Paraguay tea agroecosystem in Argentina. Florida Entomologist, Lutz, v. 77, n. 33, p. 378-382, 1994.

SHIMAZU, M. Potential of the cerambycid-parasitic type of Beauveria brongniartii (Deuteromycotina: Hyphomycetes) for microbial control of Monochamus alternatus Hope (Coleoptera: Cerambycidae). Applied Entomology and Zoology, Tsukuba, v. 29, n. 1, p. 127130, 1994.

THOMPSON, J. D.; GIBSON, T. J.; PLEWNIAK, F.; JEANMOUGIN, F.; HIGGINS, D. G. The Clustal $\mathrm{X}$ windows interface: flexible strategies for multiple sequence alignment aided by quality analysis tools. Nucleid Acids Research, Strasbourg, v. 25, n. 24, p. 48764882, 1997.

VILLACARLOS, L. T.; MEJIA, B. S.; KELLER, S. Entomophthora leyteensis Villacarlos \& Keller sp. nov. (Entomophthorales: Zygomycetes) infecting Tetraleurodes acaciae (Quaintance) (Insecta, Hemiptera: Aleyrodidae), a recently introduced whitefly on Gliricidia sepium (Jaq.) Walp. (Fabaceae) in the Philippines. Journal of Invertebrate Pathology, Urbana, v. 83, n. 1, p. 16-22, 2003.

UGINE, T. A.; WRAIGHT, S. P.; SANDERSON, J. P. Microbial biological control potential of three strains of Beauveria bassiana s.l. against greenhouse shore fly Scatella tenuicosta: assessment of virulence, mass production capacity, and effects on shore reproduction. Biological Control, Lexington, v. 65, n. 3, p. 348-356, 2013. 
XIAO, G.; YING, S. H.; ZHENG, P.; WANG, Z. L.; ZHANG, S.; XIE, X. Q.; SHANG, Y.; ST LEGER, R. J.; ZHAO, G. P.; WANG, C.; FENG, M. G. Genomic perspectives on the evolution of fungal entomopathogenicity in Beauveria bassiana. Scientific Reports, London, v. 2, n. 483, p. 1-10, 2012.
WHITE, T. J.; BRUNS, T.; LEE, S.; TAYLOR, J. W. Amplification and direct sequencing of fungal ribossomal RNA genes for phylogenetics. In: INNIS, M. A.; GELFAND, D. H.; SNINSKY, J. J.; WHITE, T. J. (Ed.). PCR protocols: a guide to methods and applications. New York: Academic Press, 1990. p. 315-322. 